\title{
Influence of Apical Foramen Lateral Opening and File Size on Cemental Canal Instrumentation
}

\author{
Ronaldo Araújo SOUZA ${ }^{1}$ \\ Yara T. Corrêa Silva SOUSA ${ }^{1}$ \\ José Antônio Poli de FIGUEIREDO² \\ João da Costa Pinto DANTAS ${ }^{3}$ \\ Suely COLOMBO ${ }^{3}$ \\ Jesus Djalma PÉCORA ${ }^{4}$ \\ ${ }^{1}$ Dental School, University of Ribeirão Preto, Ribeirão Preto, SP, Brazil \\ ${ }^{2}$ PUC - Pontifical Catholic University, Porto Alegre, RS, Brazil \\ ${ }^{3}$ Department of Endodontics, Dental School, EBMSP - Bahiana School of Medicine \\ and Public Health, Salvador, BA, Brazil \\ ${ }^{4}$ Ribeirão Preto Dental School, USP - University of São Paulo, Ribeirão Preto, SP, Brazil
}

\begin{abstract}
Since instrumentation of the apical foramen has been suggested for cleaning and disinfection of the cemental canal, selection of the file size and position of the apical foramen have challenging steps. This study analyzed the influence of apical foramen lateral opening and file size can exert on cemental canal instrumentation. Thirty-four human maxillary central incisors were divided in two groups: Group $1(\mathrm{n}=17)$, without flaring, and Group $2(\mathrm{n}=17)$, with flaring with LA Axxess burs. K-files of increasing diameters were progressively inserted into the canal until binding at the apical foramen was achieved and tips were visible and bonded with ethyl cyanoacrylate adhesive. Roots/files set were cross-sectioned $5 \mathrm{~mm}$ from the apex. Apices were examined by scanning electron microscopy at $\times 140$ and digital images were captured. Data were analyzed statistically by Student's t test and Fisher's exact test at 5\% significance level SEM micrographs showed that 19 (56\%) apical foramina emerged laterally to the root apex, whereas 15 (44\%) coincided with it Significantly more difficulty to reach the apical foramen was noted in Group 2. Results suggest that the larger the foraminal file size, the more difficult the apical foramen instrumentation may be in laterally emerged cemental canals.
\end{abstract}

Key Words: Apical foramen, coronal preflaring, endodontic files, maxillary central incisor.

\section{INTRODUCTION}

Loss of $1 \mathrm{~mm}$ of the working length increases the failure rate by $14 \%$ in teeth with periapical lesions (1). Furthermore, a working length more than $2 \mathrm{~mm}$ short of the apex represents a $20 \%$ reduction in the success rates when periapical lesions are present (2). This may be explained by the presence of microorganisms at the apical portions of the canal and their participation in the development of periapical lesions $(3,4)$.

The success of endodontic treatment depends on the eradication of microorganisms from the root canal system and prevention of reinfection (5). For such purpose, it seems reasonable to suppose that instrumentation should be carried out in the entire length of the canal, including the cementum portion, beyond the apical constriction (6-8).

Cleaning of the cemental canal with a smalldiameter K-file passively inserted through the apical constriction (9) has been questioned by Souza (8) and Hülsmann and Schäfer (10). Apical foramen widening has been demonstrated to be more favorable to the healing of chronic periapical lesions (11) and it should be performed with a file which fits closely the constriction of the canal and be followed by the next two of its type in series and size (12).

Maxillary central incisors usually have wide canals, requiring the use of large files. On the other hand, analysis of the apical anatomy of these teeth show that the apical foramen frequently emerges laterally to 
the apex (13-16).

Considering that files of large diameter present limited flexibility, it is possible that both aspects, instruments with large diameters and lateral opening of the apical foramen, pose some challenges on apical foramen widening.

The aim of the present work was to evaluate the influence of apical foramen lateral opening and file size can exert on cemental canal instrumentation in maxillary central incisors.

\section{MATERIAL AND METHODS}

Thirty-four human maxillary central incisors with fully developed roots from the tooth bank of the Dental School of the Bahiana School of Medicine and Public Health were used for this study. The criteria adopted for selection of the teeth were absence of complex external anatomy, accentuated curvature, incomplete root formation and apical resorption, as determined by direct examination and periapical radiographs. One operator performed all experimental procedures.

Access and preparation of the pulp chamber were carried out with a \#3 carbide round bur (KG Sorensen, Cotia, SP, Brazil) and Endo-Z bur (Maillefer, Ballaigues, Switzerland).

After irrigation with $1 \mathrm{~mL} 2.5 \% \mathrm{NaOCl}$, root canals were explored with a size $15 \mathrm{~K}$-file (FKG Dentaire, La-Chaux-de-Fonds, Switzerland), manually inserted until the apical foramen was reached and the tip of the file was visible. Thus, canal length was determined for all teeth.

Teeth were randomly divided into two groups. In Group $1(\mathrm{n}=17)$, canals were irrigated with $1 \mathrm{~mL} \mathrm{2.5 \%}$ $\mathrm{NaOCl}$ and K-files (FKG Dentaire) of progressively increasing diameters were gently inserted into the canal with reciprocating motion until binding at the apical foramen and its tip was visible. The diameter of this instrument was recorded and it was bonded with ethyl cyanoacrylate adhesive. Roots/files set were crosssectioned $5 \mathrm{~mm}$ from the apex.

Table 1. Mean (S.D.), minimum and maximum values and median of file size in both groups $(\mathrm{mm})$.

\begin{tabular}{lccccc}
\hline Group & Mean (S.D.) & $\begin{array}{c}\text { Mini } \\
\text { value }\end{array}$ & $\begin{array}{c}\text { Max } \\
\text { value }\end{array}$ & Median & $\mathrm{p}$ \\
\hline 1 (non-flared) & $33.82(4.85)$ & 30 & 45 & 30 & 0 \\
2 (flared) & $42.06(7.72)$ & 30 & 55 & 40 & \\
\hline
\end{tabular}

In Group $2(\mathrm{n}=17)$, coronal flaring was carried out with 20/0.06 and 35/0.06 LAAxxess burs (SybronEndo, Glendora, CA, USA), attached to an Endo-Pro torque endodontic motor (Driller, Jaguaré, ES, Brazil) at 3.5 $\mathrm{N}-\mathrm{cm}$ torque and 6,000 rpm. Burs were inserted up to $4 \mathrm{~mm}$ short of the apex and canals were irrigated with $1 \mathrm{~mL} 2.5 \% \mathrm{NaOCl}$ at each change of instrument. A $5 \mathrm{~mL}$ impression syringe and capillary tip (Ultradent Products Inc., South Jordan, UT, USA) were used for the irrigation in both groups.

After coronal flaring, a size $15 \mathrm{~K}$-file as reintroduced up to the apical foramen to reestablish patency and K-files of progressively increasing diameters were gently inserted into the canal with reciprocating motion until binding at the apical foramen and its tip was visible. The diameter of this instrument was recorded and it was bonded with ethyl cyanoacrylate adhesive. Roots/files set were cross-sectioned $5 \mathrm{~mm}$ from the apex.

The roots of both groups were fixed on stubs and gold sputtered as previously reported (17) and a scanning electron microscope Philips XL-30 (Philips, Eindhoven, Netherland) was used to examine the apices at $\times 140$ magnification. Images were captured digitally and data were analyzed statistically by Student's t-test and Fisher's exact test. A significance level of 5\% was set for all analyses.

\section{RESULTS}

The mean size of the files in each group, as well as the standard deviations, minimum and maximum values, and the medians are shown in Table 1.

The mean values of the file sizes were subjected to the Student's t-test and statistically significant differences were observed between the groups $(p=0)$. The mean size of the foraminal files (i.e., those that bound at the cemental canal) was larger in Group 2 (with flaring), as shown in Table 2. The rate differences for each file size was tested by Fisher's exact test. Statistically significant difference $(\mathrm{p}=0.047)$ was observed between sizes 30 and 35 files in Group 1, when compared with Group 2. For

Table 2. Distribution of the foraminal files in the two groups, according to their sizes.

\begin{tabular}{lcccccc}
\hline Group & $\# 30$ & $\# 35$ & $\# 40$ & $\# 45$ & $\# 50$ & $\# 55$ \\
\hline 1 (non-flared) & 9 & 4 & 3 & 1 & - & - \\
2 (flared) & 1 & 5 & 4 & 2 & 3 & 2 \\
\hline
\end{tabular}


the remaining file sizes, no significant difference was observed between the groups.

Analysis of the SEM micrographs showed that 19 (56\%) apical foramina emerged laterally to the root apex (Fig. 1A), whereas 15 (44\%) coincided with it (Fig. 1B). In Group 2 there was more difficulty when trying to insert files up to the apical foramen of some canals, especially in those with slightly curved roots (Figs. 2A and 2B).

\section{DISCUSSION}

In addition to contributing to more precise determination of the actual apical diameter $(18,19)$, another goal of access flaring is to facilitate file penetration and instrumentation of the apical third of the canal. Thus, coronal flaring should also facilitate penetration of the file up to the apical foramen.

By reducing the interferences at the cervical and middle thirds, flaring allowed larger files to bind at the apical foramen in Group 2, as shown in Tables 1 and 2. However, in this group we encountered more difficulties to insert files up to the apical foramen of some canals, particularly in those with slightly curved roots (Figs. $2 \mathrm{~A}$ and $2 \mathrm{~B}$ ). In straight roots, these difficulties were less significant.

The need for enlargement of the root canal is not justified only for mechanical (shaping) reason. There is also a biological (cleaning) reason $(20,21)$. Success of endodontic treatment depends on the eradication of microbes from the root-canal system (5) and debridement of the root canal by instrumentation and irrigation is considered the most important single factor in the prevention and treatment of endodontic diseases (22).
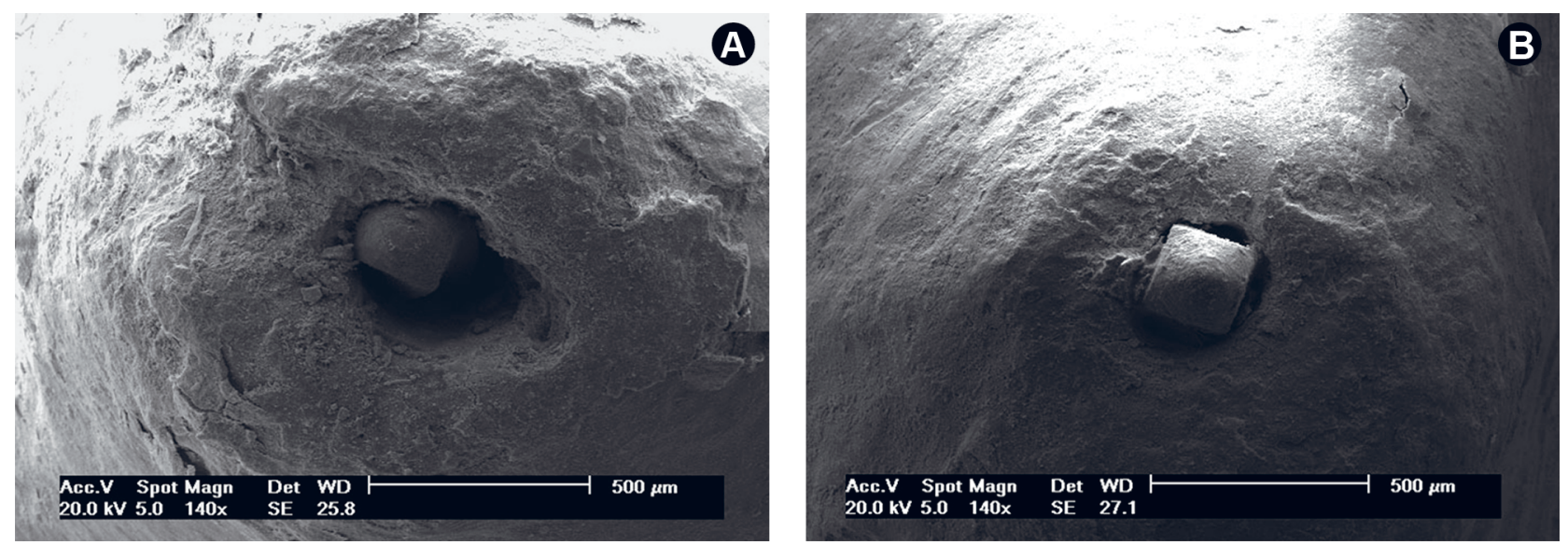

Figure 1. Location of the apical foramen in relation to the root apex. A: Apical foramen emerging laterally. B: Apical foramen coinciding with the root apex.
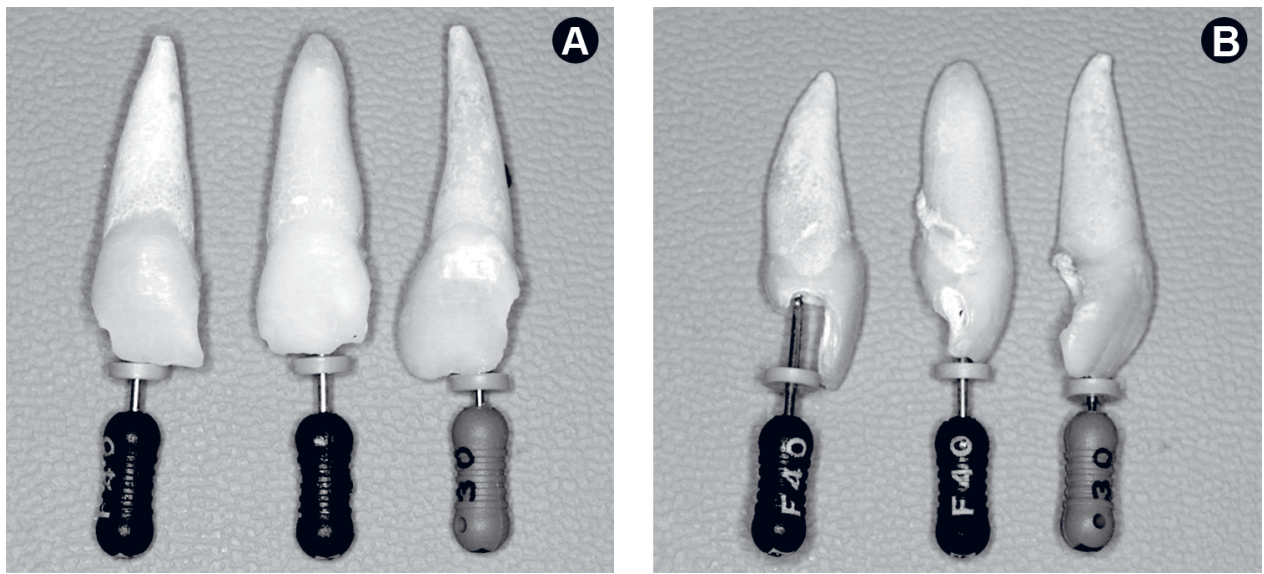

Figure 2. Shape of the maxillary central incisor roots. Observe the slightly curved roots. A: Frontal (mesiodistal) view. B: Proximal view. 
Thus, as in dentinal portion of the canal, instrumentation of the cemental canal should be considered.

Apical foramen widening is more favorable to the healing of chronic periapical lesions (11) because there are more chances to eradicate microorganisms from the root canal, particularly those in cemental canal, and promote infection control.

Butler (12) established that the apical foramen should be instrumented with a file which fits closely the constriction of the canal and be followed by the next two of its type in series and size, whereas Souza et al. (23) observed that for adequate relationship it would require 4 instruments beyond the foraminal file. However, this is not only a microbiological matter, but also an anatomic issue. In view of the foraminal file sizes (Tables 1 and 2) and the high frequency of lateral opening of the apical foramen, corroborated by other authors (13-16), widening of the apical foramen in some teeth, such as maxillary central incisors, can be difficult.

Large-diameter instruments are less flexible and therefore more difficult to bend prior to insertion in apical foramens which open laterally. It is possible that in these situations the pressure applied during insertion of the files into the apical foramen induces changes in its anatomical configuration. Despite the need of enlargement for better infection control, instrumentation with larger files may represent a challenge in laterallyemerging foramen.

In view of this, one can recommend initial penetration up to the foramen to be carried out with smaller files, which are able to reach the foramen without applying excessive pressure. In a subsequent step, larger file sizes could be used. Yet, other alternatives would be the use of more flexible instruments, such as nickeltitanium (NiTi) files, safe-adjusted file (SAF) (23), or the development of appropriate instruments for this purpose.

The present results demonstrate that the larger the foraminal file size the more difficult the apical foramen instrumentation may be in laterally emerged root canals. Further studies focusing on this topic should be conducted, including other groups of teeth.

\section{RESUMO}

Tendo em vista que a instrumentação do forame apical tem sido sugerida para a limpeza e desinfecção do canal cementário, a seleção do calibre do instrumento e a posição do forame apical representam passos desafiantes. Este estudo analisou a influência que a saída lateral do forame apical e o calibre do instrumento podem exercer na instrumentação do canal cementário. Trinta e quatro incisivos centrais superiores foram divididos em dois grupos: Grupo 1 ( $\mathrm{n}=17)$, sem preparo cervical, e Grupo $2(\mathrm{n}=17)$, com preparo cervical com brocas LA Axxess. Limas K com aumentos de diâmetro foram progressivamente inseridas no canal até ajustar no forame apical e as pontas ficarem visíveis e foram fixadas com adesivo de etil cianoacrilato. Os conjuntos raízes/ limas foram seccionados transversalmente a $5 \mathrm{~mm}$ aquém do ápice. Os ápices foram examinados por microscopia eletrônica de varredura com aumento de 140x e imagens digitais foram capturadas. Os dados foram examinados estatisticamente pelo teste t de Student e teste exato de Fischer com nível de significância de 5\%. A microscopia eletrônica de varredura mostrou que 19 $(56 \%)$ dos forames apicais saíram lateralmente em relação ao ápice radicular, enquanto que 15 (44\%) coincidiram com ele. Dificuldade significantemente maior para chegar ao forame apical foi observada no Grupo 2. Os resultados sugerem que quanto mais calibroso for o instrumento foraminal, mais difícil poderá ser a instrumentação do forame apical em canais cementários que apresentam saída lateral.

\section{REFERENCES}

1. Chugal NM, Clive JM, Spangberg L. Endodontic infection: some biologic and treatment factors associated with outcome. Oral Surg Oral Med Oral Pathol Oral Radiol Endod 2003;96:81-90.

2. Wu M-K, Wesselink PR, Walton RE. Apical terminus location of root canal treatment procedures. Oral Surg Oral Med Oral Pathol Oral Radiol Endod 2000;89:99-103.

3. Nair PNR, Henry S, Cano V, Vera J. Microbial status of apical root canal system of human mandibular first molars with primary apical periodontitis after 'one visit' endodontic treatment. Oral Surg Oral Med Oral Pathol Oral Radiol Endod 2005;99:231-252.

4. Ricucci D, Pascon EA, Ford TR, Langeland K. Epithelium and bacteria in periapical lesions. Oral Surg Oral Med Oral Pathol Oral Radiol Endod 2006;101:239-249.

5. Haapasalo M, Shen Y, Qian W, Gao Y. Irrigation in Endodontics. Dent Clin North Am 2010;54:291-312.

6. Souza RA. Clinical and radiographic evaluation of the relation between the apical limit of root canal filling and success in Endodontics. Part 1. Braz Endod J 1998;3:43-48.

7. Carrotte P. Endodontics: Part 7 Preparing the root canal. Brit Dent J 2004;197:603-613.

8. Souza RA. The importance of apical patency and cleaning of the apical foramen on root canal preparation. Braz Dent J 2006; 17:6-9.

9. Lambrianidis T, Tosounidou E, Tzoanopoulou M. The effect of maintaining apical patency on periapical extrusion. J Endod 2001;27:696-698.

10. Hülsmann M, Schäfer E. Apical patency: fact and fiction-a myth or a must? A contribution to the discussion. ENDO (London England) 2009;3:275-284.

11. Borlina SC, Souza V, Holland R, Murata SS, Gomes-Filho JE, Dezan Junior E, et al.. Influence of apical foramen widening and sealer on the healing of chronic periapical lesions induced in dogs' teeth. Oral Surg Oral Med Oral Pathol Oral Radiol Endod 2010;109:932-940.

12. Butler NP. Apical debridement - a hypothesis and preliminary report. J Br Endod Soc 1970;4:52-56.

13. Gutierrez JHG, Aguayo P. Apical foraminal openings in human teeth: number and location. Oral Surg Oral Med Oral Pathol Oral Radiol Endod 1995;79:769-777.

14. Martos J, Ferrer-Luque CM, González-Rodríguez MP, Castro LA. Topographical evaluation of the major apical foramen in 
permanent human teeth. Int Endod J 2009;42:329-334.

15. Rahimi S, Shahi S, Yavari HR, Reyhani MF, Ebrahimi ME, Rajabi E. A stereomicroscopy study of root apices of human maxillary central incisors and mandibular second premolars in an Iranian population. J Oral Science 2009;51:411-415.

16. Souza RA, Figueiredo JAP, Colombo S, Dantas JCP, Lago M, Pécora JD. Location of the apical foramen and its relationship with foraminal file size. Dent Press Endod 2011;1:64-68.

17. Vier FV, Figueiredo JAP. Prevalence of different periapical lesions associated with human teeth and their correlation with the presence and extension of apical external root resorption. Int Endod J 2002;35:710-719.

18. Pécora JD, Capelli A, Guerisoli DMZ, Spanó JC, Estrela C. Influence of cervical preflaring on apical file size determination. Int Endod J 2005;38:430-435.

19. Vanni JR, Santos R, Limongi O, Guerisoli DM, Capelli A, Pécora JD. Influence of cervical preflaring on determination of apical file size in maxillary molars: SEM analysis. Braz Dent J 2005;16:181186.

20. Chuste-Guillot MP, Badet C, Peli JF, Perez F. Effect of three nickel-titanium rotary file techniques on infected root dentin reduction. Oral Surg Oral Med Oral Pathol Oral Radiol Endod 2006;102:254-258.

21. Bonsor SJ, Nichol R, Reid TMS, Pearson GJ. An alternative regimen for root canal disinfection. Br Dent J 2006;201:101-105.

22. Haapasalo M, Endal U, Zandi H, Coil JM. Eradication of endodontic infection by instrumentation and irrigation solutions. Endod Topics 2005;10:77-102.

23. Souza RA, Sousa YTCS, Figueiredo JAP, Dantas JCP, Colombo $\mathrm{S}$, Pécora JD. Relationship between files that bind at the apical foramen and foramen openings in maxillary central incisors - A SEM Study. Braz Dent J 2011;22:455-459.

24. Metzger Z, Teperovich E, Zary R, Cohen R, Hof R. The Selfadjusting File (SAF). Part 1: Respecting the root canal anatomy - a new concept of endodontic files and its implementation. J Endod 2010;36:679-690.

Received July 25, 2011

Accepted February 3, 2012 